\title{
脳血管障害例に対寸る病巣に応じた 運動学習の進め方
}

\section{How to Proceed with Motor Learning According to the Location of Lesions Caused by Cerebrovascular Accidents}

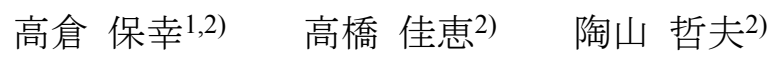

YASUYUKI TAKAKURA, RPT, PhD ${ }^{1,2)}$, Yoshie TAKAHASHI, RPT, $\mathrm{Ms}^{2)}$, TETSUO SUYAMA, MD, PhD ${ }^{2)}$

1) School of Physical Therapy, Faculity of Health and Medical Care, Saitama Medical University: 981 Kawakado, Moroyama-cho, Saitama 350-0496, Japan. TEL +81 49-295-1001 FAX +81 49-295-5104

2) Department of Rehabilitation, Saitama Medical Center, Saitama Medical University

Rigakuryoho Kagaku 22(4): 553-557, 2007. Submitted Jun. 13, 2007.

ABSTRACT: We give a summary of the method of motor learning according to the locations of the lesions caused by cerebrovascular accidents. The locations are classified as follows: a) from area 4 to the corona radiate; b) in the lower position of the internal capsule; c) in the reticular formation; d) in the limbic system; e) in the parietal lobe, temporal lobe, or occipital lobe; and f) in the frontal lobe.

Key words: CVA, CT, motor learning

要旨 : 脳血管障害例に対する病巣に応じた運動学習の進め方を概説する。具体的には，病巣が，a. 4野〜放線冠にある 場合， b. 内方レベル以下の下位にある場合， c. 網様体にある場合， d. 辺縁系にある場合， e. 頭頂葉あるいは側頭葉， 後頭葉にある場合，f. 前頭葉にある場合などに分けて説明する。

キーワード : 脳血管障害, CT, 運動学習

1) 埼玉医科大学 保健医療学部理学療法学科 : 埼玉県毛呂山町981（†350-0496） TEL 049-295-1001 FAX 049-295-5104

2) 埼玉医科大学総合医療センター リハビリテーション科

受付日 2007年6月13日 


\section{I. はじめに}

近年の研究では, 脳の局在による機能が明らかになっ てきていることから, 理学療法士も損傷されている局在 によって予想される障害の特性を推測し, その特性に応 じた運動学習の進め方を工夫することが可能となってき ている。まだまだ臨床場面では試行錯誤の段階であり, 具体的な有効性を客観的に示寸までには至っていない が，いままでの臨床経験から得られた知見を解説したい。

\section{II. 病変が4野〜放線冠にある場合}

意識的な動作では, 一次運動野から多くの信号が送 られ, 脊髄を介し筋細胞へと伝達される。この場合の意 識的動作というのは, 無意識的運動に対する反語であ り, 意識・注意をより必要とした動作のことを示す。具 体的には, 熟練した人の車の運転動作は能動的な運動で はあるが, オートマティックに動か寸要素が大きいため 意識的とは必ずしもいえない。歩行も同様に意識的とは 言えないが, 新しくダンスのステップを覚えようとする と意識・注意をより必要とし, 一次運動野からの信号が 多くなることが予想される。

病変が一次運動野である4野から伝達路の放線冠まで の間の存在に傷害を受けている場合には, 意識的な運動 が困難となる。基本動作を考えると, より強い力を発揮 しょうとしたり, 素早く動かそうとしたり, 細かな動き

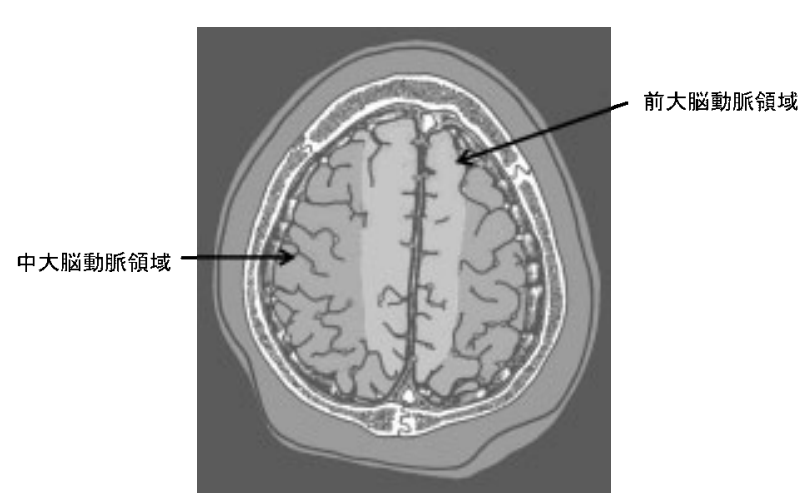

図1 頭頂部の支配動脈領域

をしようとしたりといった意識的な運動が障害される。 損傷が明瞭な場合には, 運動そのものが起こらない, あ るいは非常に弱い運動しか起こらないことが多い。損傷 が明らかでなくても, 前大脳動脈の狭窄がみられると き，あるいは同動脈領域（図1）の菱縮が著明なときな どは下肢・体幹の筋力とスピードを乗じたパワーが低下 寸ることが多く, 中大脳動脈の狭窄あるいは同動脈領域 （図1）の萎縮が著明なときは，手の巧緻性に障害が出る ことが多い。皮質脊髄路における体部位局在 (somatotopy) を覚えておくことも重要である（図2）。

この領域の障害では, いわゆるブルーンストローム ステージに示されるような病的な共同運動障害はすぐ には生じない。二次的に不良に学習された結果として,

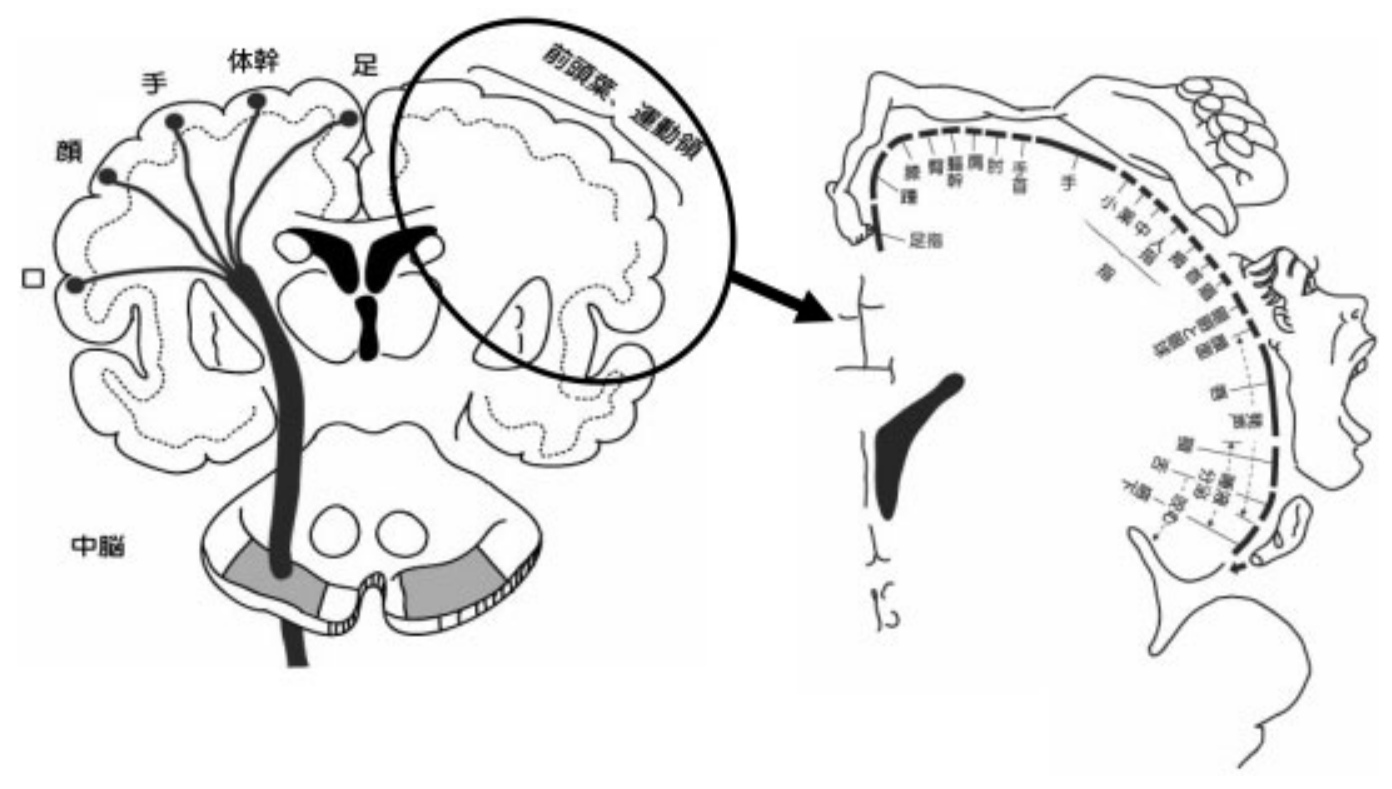

図2 錐体路（皮質脊髄路）と体部位局在 
動作パターンの異常は起こる可能性はあるが, より反 射・反応レベルに近い共同運動パターンは生じにくい。 従って, 立ち上がり運動やトレーニングマシーンを用い た運動, 歩行器などを用いた長時間の歩行練習などを積 極的に行うことが可能である。共同運動パターンの出現 を過度に意識しすぎて, 運動負荷や運動量が少なくなら ないように注意することが重要である。

\section{III. 病変が内方〜延髄にある場合}

脳出血の好発部位である内包近傍（被款, 視床）で は, 錐体路と錐体外路の線維が交差している。随意運動 を行うとき, 我々は全ての筋の活動に意識・注意を向け ているわけではない。例えば，歩こうとするときには， その準備として必要な下肢の筋緊張が高くなり,一次運 動野から錐体路を通した運動指令を錐体外路系が無意 識のうちに補助をする。内包以下の障害では, 錐体路系 と錐体外路系の協調された活動が障害されるため, いわ ゆるブルーンストロームステージに述べられているよ うな病的共同運動障害が出現しやすくなる。脳出血では 視床が被款に次ぐ好発部位である。視床は意識的な知覚 情報の中継路であるが, 単に情報を中継するだけではな く, 間脳として情報を選択するという中枢機能を果たし ている。視床が傷害されると一次的な知覚障害だけはな くより高次な知覚・認知の障害を生みやすい。半側空間 無視が視床出血で生じることは良く知られている。小脳 系では, より低位の感覚情報を介したフィードバックが 傷害され, 四肢の単純な運動が障害されることが知られ るが, 小脳の信号は前頭葉に送られることも知られてい る。適切な情報が前頭葉に送られないことから, 小脳に 傷害がある場合には擬似的に前頭葉障害と同様な症状 が出現する可能性がある。脳幹は生命維持中枢であるた め, まずは呼吸, 循環系のリスク管理がより重要とな る。脊髄障害と同様に痤縮が生じやすく, 上位中枢およ び小脳との連絡を持つことから様々な障害が生じる。脳 幹でもレベルや横断面での障害部位に異なるので傷害 部位を詳細に把握することも大切であるが, 小さな部位 に多数の重要な核や伝導路が存在するので画像からの 判断には限界もあり各症例の症状を丁寧にみていくこ とが要求される。

理学療法では, 望ましくない運動パターンを引き起 こさないように注意しながら, 望ましい運動を繰り返し 行い運動学習をすすめるというのが基本的な考え方で ある。運動パターンを記憶する前頭葉は傷害されていな いので運動記憶は可能であるが, 運動記憶は言語記憶に

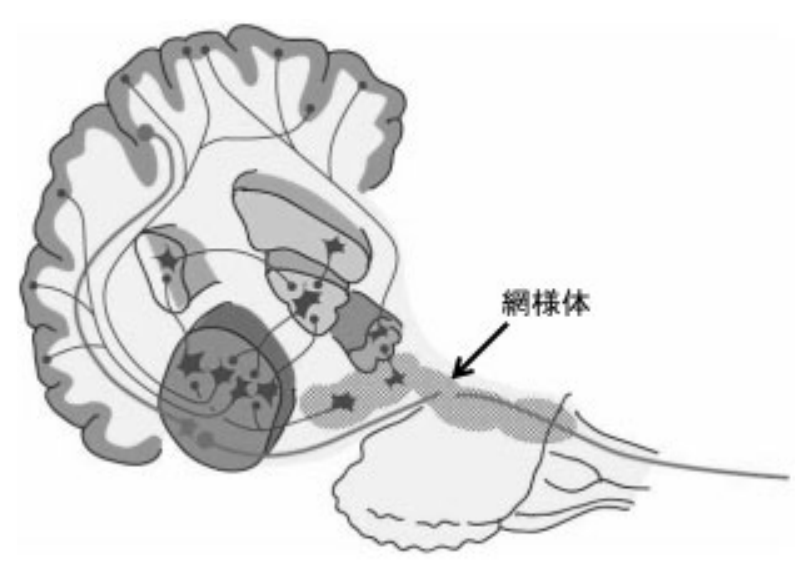

図3 網様体と網様体賦活系の模式図

網様体から始まり非特殊感覚路として大脳にびまん性に 投射する経路を網様体賦活系という。

比べより繰り返しの神経活動を必要とする。成功体験が 前頭葉の記憶を助けるので, 本人が正しい運動を行えた ことを自覚できるように工夫することも重要である。

\section{IV. 病変が網様体にある場合}

網様体は, 延髄, 橋, 中脳, 視床間に, 網様 (net-like) でびまん性に分布する細胞集団である。網様体に始まり 非特殊感覚路として大脳にびまん性に投射する経路を 網様体賦活系という（図3）。網様体が傷害されると，広 範な大脳の不活化, 意識・覚度の全般的低下が生じる。 大脳自体は傷害されていないため, 意識・覚度が高いと きには運動機能や知的機能の障害が少ないことも特徴 である。急性期のテント上部の脳血管障害例で, 占拠性 病変の存在から二次的に脳圧が充進している例では, 網 様体賦活系の機能が二次的に傷害される。ただし, 脳へ ルニアなどにより不可逆性の傷害が生じなければ回復 が期待できるので注意が必要である。

理学療法では, 意識や覚度の向上を図ると良い。具体 的には, 全身運動である立ち上がり運動, より興味を引 くような課題を取り入れた立位運動などがあげられる。 認知的な要素は, 本人が確実に課題を達成できる水準ま で落とすことが肝要である。視床出血例などで半側空閒 無視がみられる場合に, 半側空間無視という認知機能を 改善させることを考えるより, 覚度の低下がみられるよ うであれば起立練習などを行うことで覚度の向上を促 すことで, 結果的に半側空間無視の改善が得られる場合 が多い。 


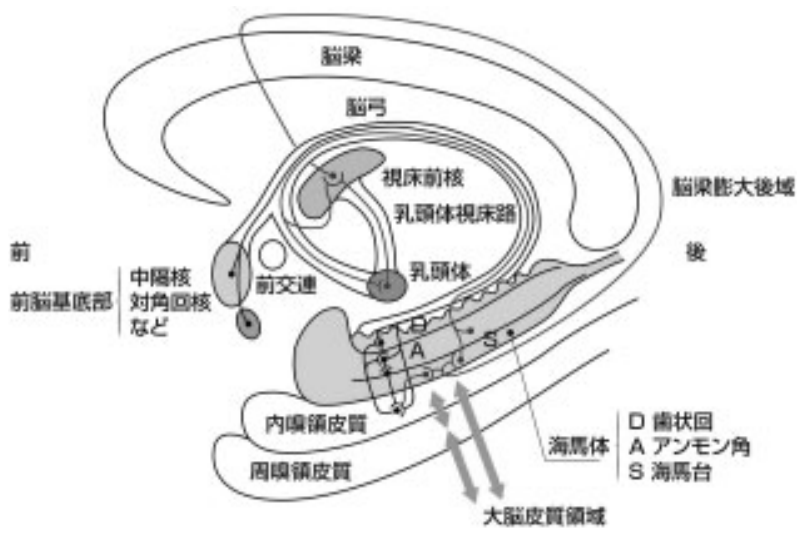

図4 Papezの回路

記憶（特に言語的な記憶）に強く関係し, 海馬一脳弓一乳頭 体一乳頭体視床路一視床前核一視床帯状回投射一帯状回一帯 状束一海馬からなる.

\section{V. 病変が辺縁系にある場合}

辺縁系は, 情緒・感情や記憶に強く関係する。Papez の回路は記憶, 特にエピソード記憶などの記憶を司る神 経回路として知られている（図4）。感情に関わる回路は Yakovlevの回路と呼ばれ, 扁桃体, 視床内側核, 前頭葉 下面を中心に形成される。Papezの回路とYakovlevの回 路の2つの神経回路は独立しているが, 多くの場所で神 経の結合が重なり合っている。前大脳動脈の動脈瘤の破 裂で, 側脳室前角を挟むように尾状核頭部と脳梁が傷害 されると著明な記憶障害が出現することが知られ, 臨床 的にしばしば遭遇する。

辺縁系が強く傷害されると, 原始的な脳の機能が傷 害されるので活動・参加は重度に障害される。多くを望 むよりも, 残されている感情や記憶能力を正確に把握 し, その残された範囲でできる活動・参加を確実に達成 していくような努力が大切である。傷害が強い場合は認 知的な要素や遂行機能の要素は最低限に抑え, 他動的な 介入による身体機能の維持や単純な刺激をトリガーと した風船バレーなどを行うと良い。

\section{VI. 病変が頭頂葉あるいは 側頭葉, 後頭葉にある場合}

我々が五感と呼ぶ, 視覚, 聴覚, 体性感覚, 味覚, 嗅 覚の一次中枢は頭頂葉, 側頭葉, 後頭葉に存在し, これ らの知覚情報を統合してより上位の知覚から認知とい う過程に至る。どこまでを知覚とするか, どこからを認

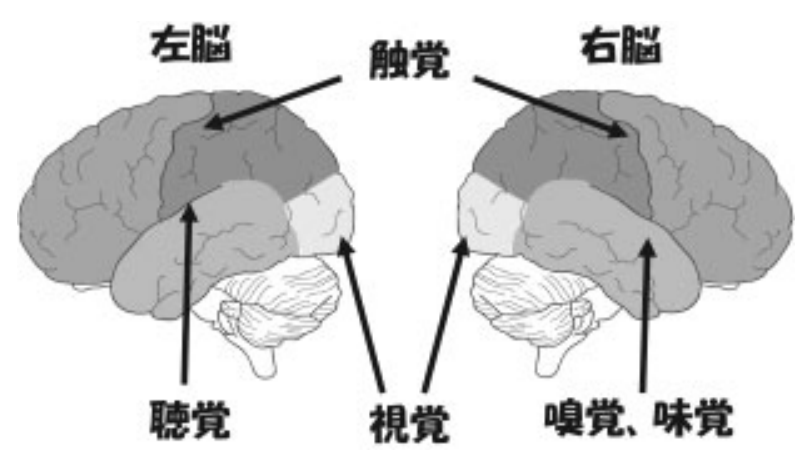

図5 五感の局在 (一次中枢)

知とするかは統一した見解はなく研究者によって異な るが, 基本的に二分化されるものではなく, 連続的に上 位の統合過程を通じて認知に至ることを理解しておく と良い。一般に，広範な認知機能の障害を持つものを認 知症と呼び, アルツハイマー型痴呆では連合野の機能が 低下することから重度な認知機能の障害が生じやすい が,脳血管性認知症では全ての知覚情報の処理が同時に 障害されることは少ない。脳血管性認知症では, 保たれ ている機能と, 障害されている機能の差が大きいことが 多く，まだら痴呆と呼ばれる由縁になっている。

認知機能が低下している例では, 保たれている, つま りトリガーとなる知覚情報を探すと良い。右半球損傷例 では言語情報を, 左半球損傷例では状況判断につながる 視覚情報や体性感覚を多く用いるようにするとうまく いくことが多い。認知症に対しては誤りなし学習の有効 性が報告されている。できない課題を助けてできるよう に促していくよりも, できる課題を数多く行い, 少しず つレベルアップしていくような考え方が大切である。

\section{VII. 病変が前頭葉にある場合}

前頭葉は，脳の中で最も高次に位置する機能を司る 脳であり, 要素的な運動機能の発現・再現機能に加え, 高次の意志決定と行動に関わる遂行機能を司る。Lezak は遂行機能を目的をもった一連の活動を有効に行うの に必要な機能と定義し, 構成要素として, (1)目的の設定 (Volition), (2)計画の立案（Planning), (3)目的に沿った 計画の実行 (Purposefull action), (4)効率性の検討 (Effective performance）をあげている。一方，前頭葉障害は多彩な 障害像を呈することが知られ, 行動観察からは, (1)本能 性把握反応，(2)問いかけに対する言語返答，(3)模倣行 動, 使用行動（環境依存症候群）, (4)自発語, (5)食事义 


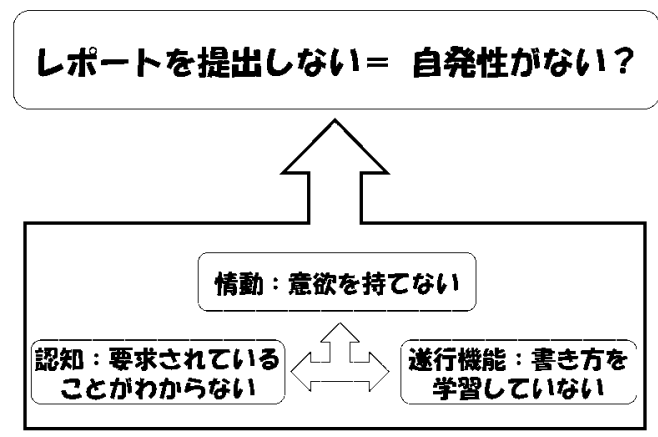

図6 自発性の考え方

実習生がレポートを提出しないようなときにも情動 と認知と遂行機能に分けて考えることが可能である.

ニューの選択, (6)本能性把握などの抑制, (7)食事活動の 継続（中断しない), (8)抽象的, 概念的な言語表現, (9) 定時の整容活動，(10排泄前の介助依頼，(11)突然のスケ ジュールの変更に対する対応などの推移がみられる。遂 行機能を理解するためには, 情動・感情の機能と認知機 能を良く理解しておく必要がある。例えば，遂行機能の 障害では自発性の低下が良く知られるが自発性の低下 は認知機能の低下や情動の低下でも生じる。遂行機能の 低下というためには, 先に情動および認知機能を確認す ることが大切である。逆に言えば，自発性をみるとき に, 情動と認知機能, 遂行機能に分けて考えると, 具体 的な理学療法プログラムの立案に大いに役立つ。

前頭葉の障害は多彩であるため, 遂行機能障害に対 寸る理学療法の考え方を一般化することは困難である。 強いて言えば, 具体的な目標を視覚的に与えること, 遂 行機能の改善を図る前に要素的な身体機能の改善を考 えることが臨床的には重要である。例えば, 口頭で必要 性を話しても離床が困難な例に対し, 車い寸を見せるだ けで離床が容易になる例は珍しくない。不適切な活動を 抑制するよりも，適切な活動を促すことの方が容易であ る。トイレをみることで実際には必要がなくても何度も トイレに行きたがるような使用行動（環境依存症候群） がみられる症例に対し，トイレに行くことを抑制するの は困難である。テレビを見せて病室への帰室を促すよう
な対応の方が容易なことが多い。適切な活動を反復して 促す中で, 運動学習を進めていきたい。

\section{VIII. おわりに}

病変に応じた運動学習の進め方を概説した。脳の機 能局在が明らかになってきており, 機能局在を解説した 成書が数多くみられるようになってきたが, 理学療法に どう結びつけるかは理学療法士自身が考えていかなけ ればならない問題である。筋力や関節可動域の重要性を 否定するものではないが, 脳の傷害に応じた運動学習を 考えるのであれば傷害された脳が司る, 運動と感覚情報 の統合, 認知機能や遂行機能などの高次脳機能との関わ りは避けて通れない。局在に応じた理学療法の進め方は まだまだ今後の課題であるがわかってきていることも 決して少なくない。一例, 一例の症例を丁寧に検討しな がら理学療法を進めていくことが必要であろう。

\section{文 献}

1) 植村研一: 脳を守り活かす. 静岡新聞社, 静岡, 1997.

2) 植村研一: 脳仕組みからみた脳の診かた(1). 臨床リ八, 2004, 13(1): $42-49$.

3) 植村研一: 脳仕組みからみた脳の診かた(2). 臨床リ八, 2004, 13(2): 136-143.

4) 内山 靖, 臼田 滋, 潮見泰藏 (編) : 神経系理学療法実践 マニュアル. 文光堂, 東京, 2003.

5) 宇野彰, 波多野和夫 (編) : 高次神経機能障害の臨床はこ こまで変わった．医学書院，東京，2002.

6) 神奈川県総合リハビリテーションセンター (監修) : 脳血管 障害による高次脳機能障害ナーシングガイド. 日総研出版, 2001.

7) 久留 裕, 真柳佳昭: 画像診断のための脳解剖と機能系. 医 学書院, 東京, 1995

8) 佐野圭司 (編) : 意識障害の評価法. 集中治療医学講座6. 医 学図書出版, 東京, 1982.

9) 杉浦和朗 : イラストによる中枢神経系の理解 (第3版)。医歯 薬出版, 東京, 1998.

10) 高木康行他：脳卒中ビジュアルテキスト（第2 版）。医学書 院, 東京, 1994.

11) 前田真治: 老人のリハビリテーション (第6版). 医学書院, 東京, 2003 . 